\title{
Umbralisib Tosylate
}

National Cancer Institute

\section{Source}

National Cancer Institute. Umbralisib Tosylate. NCI Thesaurus. Code C152795.

The tosylate form of umbralisib, an orally bioavailable, selective inhibitor of the delta is oform of the $110 \mathrm{kDa}$ catalytic subunit of class I phosphoinositide-3 kinases (PI3K) with potential antineoplastic activity. umbralisib inhibits PI3K and prevents the activation of the PI3K/AKT kinase signaling pathway. This decreases proliferation and induces cell death in susceptible tumor cells. Unlike other isoforms of PI3K, PI3K-delta is expressed primarily in tumor cells and cells of the hematopoietic lineage. The targeted inhibition of PI3K-delta allows for PI3K signaling in normal, non-neoplastic cells. PI3K, an enzyme often overexpressed in cancer cells, plays a crucial role in tumor cell regulation and survival. 